\title{
Differences in Sense of Belonging, Pride, and Mental Health in the Daegu Metropolitan Region due to COVID-19: Comparison between the Presence and Absence of National Disaster Relief Fund
}

\author{
Young-Jae Kim, Jeong-Hyung Cho and E-Sack Kim * \\ Department of Physical Education, Chung-Ang University, Seoul 06974, Korea; yjkim@cau.ac.kr (Y.-J.K.); \\ cheer1007@naver.com (J.-H.C.) \\ * Correspondence: dlaehkgg@naver.com; Tel.: +82-2-820-5386
}

Received: 15 June 2020; Accepted: 5 July 2020; Published: 7 July 2020

check for updates

\begin{abstract}
Korea's Daegu Metropolitan City once had the second highest rate of COVID-19 infection after Wuhan in China. Following the outbreak, the government provided the first national disaster relief fund to citizens as financial aid. This study investigated whether the sense of regional belonging, pride, and mental health among 550 citizens of Daegu differed between the times before and after COVID-19, based on the presence or absence of the disaster relief fund. Frequency analysis, descriptive statistical analysis, and $t$-tests were conducted using the SPSS 25.0 program. Results showed that the sense of belonging was higher after COVID-19 than before, while pride was lower. Individuals who received the disaster relief fund showed higher levels of regional belonging and pride with statistical significance. The prevalence of melancholy and depression increased after COVID-19, but the presence or absence of the fund did not lead to a significant difference. Thus, in case of a future national disaster level, provision of the disaster relief fund can raise the sense of regional belonging and pride, in order to elicit communication among local residents toward overcoming difficulties. Furthermore, during challenging disaster situations, central and local governments should provide diverse programs for the citizens' mental health care.
\end{abstract}

Keywords: COVID-19; Daegu; sense of belonging; pride; mental health; disaster relief fund

\section{Introduction}

The high infectivity of COVID-19, first confirmed in China at the end of 2019, led to an exponential increase in the rates of incidence and infection [1]. COVID-19 has now spread across the world, adversely affecting the political, economic, psychological, and social states in each country [2].

The government of the Republic of Korea recently raised the COVID-19 national crisis level to "serious" [3], and the World Health Organization (WHO) has declared COVID-19 a global pandemic [4].

For a certain period in Korea, the COVID-19 incidence rapidly fell in comparison to other countries, and the daily lives of people seemed to return to normal [5]. However, the 31st patient confirmed to have COVID-19 on 18 February 2020, in Daegu Metropolitan City (Daegu) in Korea led to approximately 5300 additional confirmed patients within 15 days [6]. This spread of infection resulted in the United States raising the travel alert level to the highest phase, at 4, to prohibit trips to Daegu [7]. The rapid spread of COVID-19, however, turned out not just to be a situation in Daegu, Korea; the large number of confirmed cases in New York in the United States and the sudden rise in mortality paralyzed the city [8], and led to shortage of mortuaries in the city's hospitals [9].

Daegu in Korea was designated as a disaster area, due to the large-scale spread of COVID-19. For the first time, the city provided "disaster relief funds" to citizens after the outbreak of COVID-19 [10]. 
The funds were determined to prioritize the class that had difficulty receiving national welfare for COVID-19 [11].

However, the households that exceed the standard of the national health insurance premium by $100 \%$, teaching staff and employees of public institutions are not eligible for disaster relief funds [12]. Daegu has offered prepaid cards, local currency, and gift cards that could only be used to help the financially distressed citizens and the local economy during the COVID-19 pandemic. This has been contributing to the revitalization of the local economy [13].

According to Park [14], overcoming regional economic difficulties is one of the ways of making citizens feel a sense of stability and a sense of belonging. Park [15] also stated that feeling proud of contributing to the restoration of a local market by using local currency leads to a sense of belonging to and affection for the community, and provides a chance to change the social atmosphere depressed by COVID-19 in a positive way.

The local residents of a city with a high number of confirmed COVID-19 cases may suffer from subsequent psychological trauma [16]. Such emotional damage could reduce residents' sense of regional belonging, as well as solidarity [17]. Thus, the basic data of the residents' sense of belonging and pride are necessary for those in regions, including Daegu, where COVID-19 incidence is high.

A terrifying aspect of COVID-19 is the ambiguity of the information regarding the factors related to the propagation, latency, geographical range, infection frequency, and actual mortality. In fact, an incorrect piece of information could induce anxiety and fear in people, which has a direct negative influence on mental health $[18,19]$. To understand the psychological and emotional impact of a pandemic, feelings like fear and rage have to be considered. The feeling of fear is a basic human psychological response to a potentially threatening incidence [20]. Nonetheless, continuing fear could exert harmful influence on mental health [21]. National disasters, such as the Ebola virus, severe acute respiratory syndrome outbreaks, and earthquakes, have been shown to have a negative influence on mental health [22-24]. When combating infectious diseases, fear increases the levels of anxiety and stress in healthy individuals, while aggravating the symptoms in those already suffering from a mental disorder, thus deteriorating their health further [25].

Quality of life and health are influenced by the balance between work and life, suggesting that quality of life could be enhanced when a healthy mind and lifestyle achieve harmony [26]. Hence, maintaining the quality of life at an adequate level is likely to improve the defense mechanism against stress and produce emotional stability [27].

A study on mental health among citizens of Hong Kong after the COVID-19 outbreak reported that mental health was influenced by COVID-19 [28]. The continuous spread of COVID-19 has resulted in a deterioration of the quality of life of Daegu citizens, and several people are experiencing reduced mental health [29]. Therefore, this study aimed to determine the necessary factors to aid people when a national disaster occurs, such as in the case of Daegu, while examining the needs of people during the spread of COVID-19. Furthermore, the sense of belonging, pride, and mental health as experienced by the citizens of Daegu was investigated, as Daegu is the city with the largest number of COVID-19 cases in Korea, and the differences based on the presence or absence of the national disaster relief fund was examined.

\section{Materials and Methods}

\subsection{Study Design}

This study analyzes the difference between the present and the past with group infection, based on the data of "Social Indices of Daegu in 2018" [30] and "Regional Health Statistics at a glance, 2008-2018" [31], published in the Daegu area before the COVID-19. A comparison between the presence and absence of national disaster relief fund. The data collection period was from 8 May to 13 May 2020. 


\subsection{Participants}

A survey was conducted among Daegu residents aged 19-65 years, excluding adolescents and older adults. Convenience sampling was used, and a self-reported questionnaire was administered. The survey (550 sheets) was conducted online through EMBRAIN, the top survey company in Korea. Consent for participation was obtained from each participant using a preliminary question set, before conducting the survey. The study design was reviewed and approved by the Institutional Review Board at Chung-Ang University (1041078-202005-HRSB-119-01).

\subsection{Measurement}

To investigate the differences in pride, sense of belonging, and mental health among Daegu citizens with respect to COVID-19, the following measurement tools were used. The questionnaire required $10 \mathrm{~min}$ on average for completion.

\subsubsection{Indicators of Sense of Belonging and Pride}

To measure regional pride of Daegu citizens and its levels, a scale was developed, based on "Social Indices of Daegu in 2018" [30]. The sub-categories of a sense of belonging and pride were comprised of a total of two questions: one question about a sense of belonging as a Daegu citizen and one question about satisfaction. Based on the four-point Likert scale, the scale of a sense of belonging and pride contains four sentences regarding a sense of belonging: "Very strong sense of belonging", "A little sense of belonging", "Little no sense of belonging", and "No sense of belonging at all". There were also four sentences regarding pride: "Very strong sense of pride", "A little sense of pride", "Little no sense of pride", and "No sense of pride at all".

\subsubsection{Indicators of Mental Health}

Indicators of the mental health status of the citizens were based on the "Regional Health Statistics at a glance, 2008-2018" [31] survey conducted by the Ministry of Health and Welfare and the Korea Centers for Disease Control. The sub-category of mental health was comprised of one question on average daily sleep time and stress awareness, one question on the experience of the feeling of melancholy, and nine questions on the prevalence of depression. The sleep time diagnosis consisted of average daily sleep time was measured. The stress was composed of a four-point scale, and the degree of stress perceived by individuals was indicated. The melancholy experience was usually composed of yes or no, as a question about melancholy. Among the questions, the one regarding depression prevalence used the standardized Korean version of the nine-item Patient Health Questionnaire (PHQ-9), which is a screening tool for depression comprised of nine questions, based on the Diagnostic and Statistical Manual of Mental Disorders, 4th edition [32]. Based on the diagnosis of the prevalence of depression, $0=$ "not at all", 1 = "several days", 2 = "more than half the days", and $3=$ "nearly every day" were the criteria used to diagnose the prevalence of depression. The total score ranged 0 from 27 , and a higher score means a higher incidence of depression [32]. The tool has been reported to have better sensitivity (88\%) and specificity $(88 \%)$ than the Self-Rating Depression Scale and Beck Depression Inventory, which are the most commonly used depression indicators. PHQ-9 has also been found to be valid, with a high level of reliability in the measurement of the severity of depression [33]. Despite the small number of questions that require less time for completion, the PHQ-9 has been reported as a more accurate diagnostic tool for depression in numerous recent studies [34]. This assumes significance in the present time, when almost half of the patients with depression remain undiagnosed, owing to insufficient consultation time in overcrowded outpatient clinics, or wherein most depression patients are examined primarily for physical symptoms like pain or reduced physical functions, rather than psychological ones [35]. In the present study, the Cronbach's alpha coefficient of the PHQ-9 was 0.88. 


\subsection{Data Analysis}

All data in this study were analyzed using SPSS version 25.0 (IBM, Armonk, NY, USA), after a process of coding and data cleaning. For demographic factors, cross-analysis and descriptive statistical analysis were performed, and the results compared in order to analyze the mean and standard deviation from the "Social Indices of Daegu in 2018" and the "Regional Health Statistics at a Glance, 2008-2018". to ensure the required level of confidence in each tool, Cronbach's $\alpha$ values were computed. Lastly, in order to identify the differences according to provision of the national disaster relief fund, an independent $t$-test was carried out.

\section{Results}

Table 1 displays the characteristics of the participants. This study targeted 285 females (51.8\%) and 265 males (48.2\%), which means more females participated in the study. Also, 138 people in their $20 \mathrm{~s}(25.1 \%)$ occupied the highest proportion of the subjects, and it was followed by 137 in their $40 \mathrm{~s}$ $(24.9 \%)$. There were statistically significant differences in age, monthly household income, and sense of pride depending on national disaster relief funds. Also, there were significant differences in national disaster relief funds depending on the PHQ-9 scores of the subjects.

Table 1. Demographic characteristics $(n=550)$.

\begin{tabular}{|c|c|c|c|c|}
\hline Variable & Total & WDRF $^{1}$ & WODRF $^{2}$ & $p$-Value \\
\hline$n$ & 550 & 264 & 286 & \\
\hline \multicolumn{5}{|l|}{ Gender } \\
\hline Male, $n(\%)$ & $265(48.2)$ & $128(48.3)$ & 137 (51.7) & \multirow{2}{*}{0.891} \\
\hline Female, $n(\%)$ & $285(51.8)$ & $136(47.7)$ & $149(52.3)$ & \\
\hline Age, mean (SD) & $38.33(10.64)$ & $38.09(10.66)$ & $38.54(10.64)$ & \multirow{6}{*}{0.017} \\
\hline $20 \mathrm{~s}, n(\%)$ & $138(25.1)$ & $69(50.0)$ & $69(50.0)$ & \\
\hline $30 \mathrm{~s}, n(\%)$ & $190(34.5)$ & $88(46.3)$ & $102(53.7)$ & \\
\hline $40 \mathrm{~s}, n(\%)$ & $137(24.9)$ & $73(53.3)$ & $64(46.7)$ & \\
\hline $50 \mathrm{~s}, n(\%)$ & $66(12.0)$ & $21(31.8)$ & $45(68.2)$ & \\
\hline $60-65$ years $n(\%)$ & $19(3.5)$ & $13(68.4)$ & $6(31.6)$ & \\
\hline \multicolumn{5}{|l|}{ Marital Status } \\
\hline Single, $n(\%)$ & $285(51.8)$ & $131(46.0)$ & $154(54.0)$ & \multirow{3}{*}{0.365} \\
\hline Married, $n(\%)$ & $249(45.3)$ & $123(49.4)$ & $126(50.6)$ & \\
\hline Widowed or divorced, $n(\%)$ & $16(2.9)$ & $10(62.5)$ & $6(37.5)$ & \\
\hline \multicolumn{5}{|l|}{ Education } \\
\hline Under high school, $n(\%)$ & $52(9.5)$ & $29(55.8)$ & $23(44.2)$ & \multirow{5}{*}{0.228} \\
\hline College (2-year), $n(\%)$ & $124(22.5)$ & $62(50.0)$ & $62(50.0)$ & \\
\hline University (4-year), $n(\%)$ & $307(55.8)$ & $149(48.5)$ & $158(51.5)$ & \\
\hline Master's degree, $n(\%)$ & $54(9.8)$ & $20(37.0)$ & $34(63.0)$ & \\
\hline PhD degree, $n(\%)$ & $13(2.4)$ & $4(30.8)$ & $9(69.2)$ & \\
\hline \multicolumn{5}{|l|}{ Monthly household income ${ }^{a}$} \\
\hline Under 1,000,000, $n(\%)$ & $22(4.0)$ & $17(77.3)$ & $5(22.7)$ & \multirow{8}{*}{$0.000 *$} \\
\hline \# 1,000,000-1,990,000,n (\%) & $32(5.8)$ & $23(71.9)$ & $9(28.1)$ & \\
\hline 2, $000,000-2,990,000, n(\%)$ & $118(21.5)$ & $68(57.6)$ & $50(42.4)$ & \\
\hline 3,000,000-3,990,000, $n(\%)$ & $90(16.4)$ & $47(52.2)$ & $43(47.8)$ & \\
\hline 4,000,000-4,990,000, $n(\%)$ & $84(15.3)$ & $35(41.7)$ & $49(58.3)$ & \\
\hline 5,000,000-5,990,000, $n(\%)$ & $86(15.6)$ & $39(45.3)$ & $47(54.7)$ & \\
\hline 6,000,000-6,990,000, $n(\%)$ & $50(9.1)$ & $17(34.0)$ & $33(66.0)$ & \\
\hline$\pm \geq 7,000,000, n(\%)$ & $68(12.4)$ & $18(16.5)$ & $50(73.5)$ & \\
\hline
\end{tabular}


Table 1. Cont.

\begin{tabular}{|c|c|c|c|c|}
\hline Variable & Total & WDRF $^{1}$ & WODRF $^{2}$ & $p$-Value \\
\hline Sleep time, mean (SD) & $6.77(1.16)$ & $6.77(1.20)$ & $6.76(1.13)$ & 0.946 \\
\hline \multicolumn{5}{|l|}{ Stress levels } \\
\hline I feel a lot of stress frequently & $57(10.4$ & $28(49.1)$ & $29(50.9)$ & \multirow{4}{*}{0.713} \\
\hline I feel stress a lot & $176(32.0)$ & $84(47.7)$ & $92(52.3)$ & \\
\hline I feel stress a little & $281(51.1)$ & $138(49.1)$ & $143(50.9)$ & \\
\hline I do not feel stress & $36(6.5)$ & $14(38.9)$ & $22(61.1)$ & \\
\hline \multicolumn{5}{|l|}{ Melancholy } \\
\hline Yes & 104 (18.9) & $55(52.9)$ & $49(47.1)$ & \multirow[t]{2}{*}{0.268} \\
\hline No & $446(81.1)$ & $209(46.9)$ & $237(53.1)$ & \\
\hline \multicolumn{5}{|l|}{ PHQ-9 } \\
\hline PHQ-9 score 0-4 (minimal) & $266(48.4)$ & $117(44.0)$ & $149(56.0)$ & \multirow{5}{*}{0.004} \\
\hline PHQ-9 score 5-9 (mild) & $173(31.5)$ & $88(50.9)$ & $85(49.1)$ & \\
\hline PHQ-9 score 10-14 (moderate) & $77(14.0)$ & $46(59.7)$ & $31(40.3)$ & \\
\hline $\begin{array}{l}\text { PHQ-9 score 15-19 } \\
\text { (moderately severe) }\end{array}$ & $23(4.2)$ & $5(21.7)$ & $18(78.3)$ & \\
\hline PHQ-9 score 20-27 (severe) & $11(2.0)$ & $8(72.7)$ & $3(27.3)$ & \\
\hline \multicolumn{5}{|l|}{ Sense of belonging } \\
\hline Very strong sense of belonging & $68(12.4)$ & $36(52.9)$ & $32(47.1)$ & \multirow{4}{*}{0.174} \\
\hline A little sense of belonging & $282(51.3)$ & $141(50.0)$ & $141(50.0)$ & \\
\hline Little no sense of belonging & $163(29.6)$ & $75(46.0)$ & $88(54.0)$ & \\
\hline No sense of belonging at all & $37(6.7)$ & $12(32.4)$ & $25(67.6)$ & \\
\hline \multicolumn{5}{|l|}{ Sense of pride } \\
\hline Very strong sense of pride & $41(7.5)$ & $27(65.9)$ & $14(34.1)$ & \multirow{4}{*}{0.012} \\
\hline A little sense of pride & $163(29.6)$ & $82(50.3)$ & $81(49.7)$ & \\
\hline Little no sense of pride & $259(47.1)$ & $124(47.9)$ & $135(52.1)$ & \\
\hline No sense of pride at all & $87(15.8)$ & $31(35.6)$ & $56(64.4)$ & \\
\hline
\end{tabular}

Notes: ${ }^{1}$ WDRF: with disaster relief fund; ${ }^{2}$ WODRF: without disaster relief fund; ${ }^{\text {a }}$ South Korean 10.000 won (USD $1=\mathrm{KRW}$ 1203.00). The $p$-values were calculated from chi-square tests and $t$-tests, as appropriate. ${ }^{*}$ Significant difference noted in the comparison between four groups $(p<0.05)$.

Table 2 includes a descriptive statistics analysis to determine the sleep time, stress level, melancholy and depression prevalence, sense of belonging, and sense of pride among Daegu citizens before and during COVID-19. Looking at the results, it was found that in 2016, the sleep time was at $6.6 \mathrm{~h}$ in 2016 and $6.8 \mathrm{~h}$ in the case of COVID-19. The stress level was $23.3 \%$ in 2018 and $42.4 \%$ with the current COVID-19. The depression was at $3.4 \%$ in 2018 and at $18.9 \%$ during COVID-19. The prevalence of depression was $1.9 \%$ in 2018 and $5.8 \%$ as of the emergence of COVID-19.

For the sense of belonging as a citizen of Daegu, "Very strong sense of belonging" was the lowest, at 5.9\% in 2018-as of COVID-19, it was 12.4\%. "A little sense of belonging" was at 47.2\% in 2018, and 51.3\% as of COVID-19. "Little no sense of belonging" was at 36.9\% in 2012 and 2016, and 29.6\% during COVID-19. "No sense of belonging at all" was at 2.0\% in 2012, and 6.7\% with COVID-19. Regarding pride, the "Very strong sense of pride" response was the lowest, at $5.6 \%$ in 2016 and currently at $7.5 \%$ during COVID-19. "A little sense of pride" was at 39.8\% in 2018, and 29.6\% during COVID-19. "Little no sense of pride" was at $43.0 \%$ in 2016, and COVID-19 responses were at $47.1 \%$. Lastly, "No sense of pride at all" had 3.2\% in 2012 and 15.8\% with COVID-19. 
Table 2. The mean and standard deviation (SD) of the mental health indicators, sense of belonging, and pride among Daegu citizens before and during COVID-19 $(n=550)$.

\begin{tabular}{cccccc}
\hline Items & $\mathbf{2 0 1 2}$ & $\mathbf{2 0 1 4}$ & $\mathbf{2 0 1 6}$ & $\mathbf{2 0 1 8}$ & COVID-19 \\
\hline Sleep time (hours), mean (SD) & 6.7 & 6.7 & 6.6 & 6.7 & $6.8(1.16)$ \\
Stress levels, \% (n) & 27.2 & 26.0 & 26.6 & 23.3 & $42.4(233)$ \\
Melancholy, mean (SD) & 5.6 & 5.4 & 4.9 & 3.4 & $18.9(0.39)$ \\
Depression prevalence, mean (SD) & & & & 1.9 & $5.8(5.05)$ \\
\hline Sense of belonging & & & & & \\
Very strong sense of belonging, \% (n) & 9.9 & 8.3 & 7.1 & 5.9 & $12.4(68)$ \\
A little sense of belonging, \% $(n)$ & 51.2 & 49.2 & 50.8 & 47.2 & $51.3(282)$ \\
Little no sense of belonging, \% $(n)$ & 36.9 & 38.7 & 36.9 & 41.2 & $29.6(163)$ \\
No sense of belonging at all, \% $(n)$ & 2.0 & 3.8 & 5.2 & 5.8 & $6.7(37)$ \\
\hline Sense of pride & & & & & \\
Very strong sense of pride, \% $(n)$ & 7.7 & 7.5 & 5.6 & 5.9 & $7.5(41)$ \\
$\quad$ A little sense of pride, \% $(n)$ & 47.2 & 43.0 & 45.8 & 39.8 & $29.6(163)$ \\
Little no sense of pride, \% $(n)$ & 42.0 & 45.5 & 43.0 & 48.0 & $47.1(259)$ \\
No sense of pride at all, \% $(n)$ & 3.2 & 4.1 & 5.6 & 6.3 & $15.8(87)$ \\
\hline
\end{tabular}

Table 3 shows the independent $t$-test to determine whether each parameter showed differences according to provision of the disaster relief fund. It shows that all parameters exhibited differences between the presence and absence of the fund (sense of pride: $t=3.06, p=0.002$; sense of belonging: $t=2.01, p=0.045)$.

Table 3. The differences between presence and absence of the national disaster relief fund $(n=550)$.

\begin{tabular}{|c|c|c|c|c|c|}
\hline \multirow[b]{2}{*}{ Items } & \multicolumn{2}{|c|}{ Mean (SD) } & \multirow[b]{2}{*}{ Effect Size } & \multirow[b]{2}{*}{$t$-Value } & \multirow[b]{2}{*}{$p$-Value } \\
\hline & $\begin{array}{l}\text { WDRF }^{1} \\
(n=264)\end{array}$ & $\begin{array}{c}\text { WODRF }^{2} \\
(n=286)\end{array}$ & & & \\
\hline PHQ-9, mean (SD) & $1.85(0.97)$ & $1.74(0.95)$ & 0.12 & 1.40 & 0.163 \\
\hline $\begin{array}{l}\text { Depression } \\
\text { prevalence }\end{array}$ & $1.67(0.57)$ & $1.62(0.55)$ & -0.09 & 1.01 & 0.312 \\
\hline Stress levels * & $2.52(0.76)$ & $2.55(0.78)$ & -0.04 & -0.45 & 0.650 \\
\hline Melancholy * & $1.79(0.41)$ & $1.83(0.38)$ & -0.10 & -0.10 & 0.269 \\
\hline Sense of belonging & $2.76(0.74)$ & $2.62(0.80)$ & 0.17 & 2.01 & 0.045 \\
\hline Sense of pride & $2.39(0.83)$ & $2.18(0.80)$ & 0.26 & 3.06 & 0.002 \\
\hline
\end{tabular}

Notes: $p$-values were analyzed using the independent $t$-test. ${ }^{1}$ WDRF: with disaster relief fund; ${ }^{2}$ WODRF: without disaster relief fund. * Depression prevalence, stress levels, and melancholy each showed no significant difference.

The independent $t$-test to determine whether each parameter showed differences, according to provision of the disaster relief fund, showed that none of the parameters showed a difference between presence and absence of the fund, with the following results: depression prevalence, $t=1.01, p=0.312$; stress levels, $t=-0.454, p=0.650$; and melancholy, $t=-0.106, p=0.269$.

\section{Discussion}

This study aimed to investigate whether COVID-19 had led to differences in the sense of regional belonging, pride, and mental health among the citizens of Daegu, and to analyze the differences based on the presence or absence of the national disaster relief fund. The findings are discussed as follows.

First, the sense of regional belonging was found to have increased after COVID-19 when compared to the time before. Daegu was pointed out as the source of the explosive spread of COVID-19 by the general public, who criticized the citizens of Daegu and posted various expressions of hate on online portal sites and communities, holding them responsible for the COVID-19 outbreak incessantly [36]. Such accusations and discriminating behaviors from people in other regions are thought to have led to the increased sense of belonging among the people of Daegu. In the same context, as the people in other 
regions blamed the citizens of Daegu, the increased social sharing among the local residents enhanced the regional identity, and subsequently, the regional belonging. Daegu has endured a number of disasters in the past, such as a gas explosion and metro fire, and in each case, the disaster was overcome by the united efforts of the citizens [37]. This is presumed to be the reason behind the increased sense of regional belonging among the citizens of Daegu after COVID-19.

Individuals who received the national disaster relief fund were found to have higher awareness of regional belonging. Financial difficulties in households are being relieved by the disaster relief fund provided by the government [38]. It is thus presumed that the fund is financially aiding small business owners and socially disadvantaged groups to help them overcome the difficult time [39], and individuals who received the fund are consequently showing higher awareness of regional belonging [40]. The disaster relief fund was reported to have a positive influence on the quality of life of the working poor and people with disabilities, who are able to make less than half their original profits owing to the COVID-19 outbreak [41]. Thus, in a prolonged national disaster situation, as is the case of COVID-19, with consequently reduced social and economic activities, providing the national disaster relief fund to citizens, starting with small business owners and the socially disadvantaged, was found to have led to higher awareness of regional belonging among the citizens. Such an increase in regional belonging is likely to strengthen the solidarity among local residents, and the resulting social unity would help the citizens overcome the difficult situation, based on the strong confidence regarding the region, in case of a national disaster in the future.

The regional pride among the citizens of Daegu was shown to have decreased from 2018 after the arrival of COVID-19. This finding contradicts a previous study [42]. It has been reported that the number of additional confirmed patients have substantially decreased in Daegu, Korea-a city that had faced the first phases of COVID-19 outbreak outside China. In reality, however, Daegu is viewed by its citizens as a city where such a social difficulty or disaster may occur again at any time, even though might have overcome the COVID-19 situation, which consequently led to the fall in their regional pride.

This study shows that individuals who received national disaster relief funds had a higher level of pride. According to a previous study, the people of Daegu show high levels of unity, justice, and resourcefulness [43]. This is thought to have increased an already high level of regional pride among the citizens when the national disaster relief fund was provided. Thus, based on an already high level of regional pride, the sense of community among the citizens of Daegu is likely to have increased, and the fund is thought to have further increased their regional pride. Thus, the national disaster relief fund provided to the citizens of Daegu has led to trust towards the region, owing to regional characteristics like conservative ideas, loyalty, and exclusivity; such trust may serve as the basis for communication among local residents, which would help characterize Daegu as a city that can overcome any disaster in the future.

The rate of experiencing melancholy and depression among the citizens of Daegu after COVID-19 was shown to have increased. In addition, no significant difference was found for these parameters with respect to provisions of the disaster relief fund, based on the results of the $t$-test. This indicates that the presence or absence of the fund did not have a significant impact on people's mental health, and that COVID-19 itself is presumed to have had a negative influence on the mental health of the citizens. Hence, the reduced mental health compared to the past is thought to have resulted from the social isolation, staying indoors, and altered daily activities caused by COVID-19. Indicators such as melancholy, depression, and anxiety among the citizens of Hong Kong after COVID-19 showed far higher values than the time before, which is consistent with the results in this study [28]. The continuous increase in the level of melancholy due to COVID-19 among Daegu citizens has even led to coining of the term "Corona Blues", combining the coronavirus and melancholy (blues) [44]. The level of melancholy is thought to have increased in line with the increased anxiety among Daegu citizens, due to the rapid spread of COVID-19, which once led to as high as 741 confirmed patients a day. The social distancing from friends and family due to COVID-19 has led many people to suffer 
from melancholy [45]. In addition, the changed economic and social values and relationships after COVID-19 are exerting an influence on the psychological stress in people [46]. The findings of these previous studies were partially in agreement with those of the present study. Uncertain situations about COVID-19 have resulted in increased stress and anxiety about not maintaining daily life [47]. In the future, therefore, when a focused disaster situation occurs in a single city as in the case of Daegu, various methods should be sought to reduce the levels of melancholy and stress among the citizens for their mental health care through the use of different media, including phone and the internet, or through a national program developed for the emotional stability of the citizens.

This study has several limitations, as follows. First, the data of the study were gathered online with the use of a professional survey company. For this reason, the way of responding might be influenced by using a computer and computer skills. Second, this is a cross-sectional study, which means it is impossible to observe temporary changes in respondents' sense of belonging, pride, and mental health. Third, the study results cannot apply to other regions and groups in Korea for generalization. Fourth, although giving national disaster relief funds may influence a sense of belonging and pride, these can be boosted by more diverse psychological and social factors. That is why it is impossible to generalize the levels of a sense of belonging and pride revealed in this study.

\section{Conclusions}

This study examined the differences in the sense of regional belonging, pride, and mental health among the citizens of Daegu, due to COVID-19, between the times before and after COVID-19, and based on the presence or absence of the national disaster relief fund.

The level of regional belonging among the citizens increased after COVID-19, but the level of pride decreased. Regarding differences according to provision of the national disaster relief fund, all parameters of belonging and pride significantly increased among individuals who received the fund. This was thought to be due to the enhanced regional identity, based on the characteristics of Daegu citizens, which involve conservative ideas, local patriotism, loyalty, exclusivity, and faithfulness, combined with the social convention to overcome a difficult situation together. Therefore, in a challenging national situation, providing the disaster relief fund to the citizens is anticipated to raise the sense of regional belonging and pride to enhance regional identity and elicit communication among local residents, whereby the challenge can be overcome.

Furthermore, the citizens of Daegu were found to have experienced melancholy more frequently after COVID-19, and the depression prevalence was also higher compared to the time before COVID-19. In line with this, to protect the mental health of individuals in a national disaster, such as COVID-19, every local government should take initiatives to enhance the mental health of the citizens, and in a narrower sense, a way to enhance the mental health should be sought through the provision of aids to each household, so that the family members can acquire emotional stability.

Author Contributions: Conceptualization, Y.-J.K. and E.-S.K.; methodology, Y.-J.K., J.-H.C. and E.-S.K.; validation, Y.-J.K. and E.-S.K.; formal analysis, Y.-J.K., J.-H.C. and E.-S.K.; investigation, Y.-J.K. and E.-S.K.; data curation, Y.-J.K. and E.-S.K.; writing—original draft preparation, Y.-J.K.; writing—proofreading and editing, Y.-J.K., J.-H.C. and E.-S.K. Both authors have read and agreed to the published version of the manuscript. All authors have read and agreed to the published version of the manuscript.

Funding: This research received no external funding.

Conflicts of Interest: The authors declare no conflict of interest. 


\section{References}

1. Ornell, F.; Schuch, J.B.; Sordi, A.O.; Kessler, F.H.P. “Pandemic fear” AND COVID-19: Mental health burden and strategies. Braz. J. Psychiatry 2020, 42, 232-235. [CrossRef]

2. Van Bavel, J.J.; Baicker, K.; Boggio, P.S.; Capraro, V.; Cichocka, A.; Cikara, M.; Drury, J. Using social and behavioural science to support COVID-19 pandemic response. Nat. Hum. Behaviour. 2020, 4, 460-471. [CrossRef] [PubMed]

3. Phase VI Pandemic, the Highest Alert Level, and the Second Declaration after the Swine Flu in 2009. Available online: http://www.donga.com/news/article/all/20200223/99833909/1 (accessed on 27 May 2020).

4. Grasselli, G.; Pesenti, A.; Cecconi, M. Critical care utilization for the COVID-19 outbreak in Lombardy, Italy: Early experience and forecast during an emergency response. JAMA 2020, 323, 1545-1546. [CrossRef] [PubMed]

5. “COVID-19 Will End Soon," says President Moon. Available online: https://news.joins.com/article/23705968 (accessed on 27 May 2020).

6. Choi, S.; Ki, M. Estimating the reproductive number and the outbreak size of COVID-19 in Korea. Epidemiology and Health 2020, 42, E2020011. [CrossRef]

7. Lee, H.S. "Travel Regulations May be Reinforced on 'Certain Countries' of High COVID-19 Incidence," said President Trump. Available online: http://news.chosun.com/site/data/html_dir/2020/03/03/2020030301684. html (accessed on 27 May 2020).

8. Yin, H.; Liu, Z.; Kammen, D.M. Impacts of Early Interventions on the Age-Specific Incidence of COVID-19 in New York, Los Angeles, Daegu and Nairobi. medRxiv 2020. [CrossRef]

9. How South Korea Successfully Battled COVID-19 While the U.S. Didn't. Available online: https://www. healthline.com/health-news/what-south-korea-has-done-correctly-in-battling-covid-19 (accessed on 28 May 2020).

10. Daegu to Offer Emergency Aid to Virus-Battered Households, Businesses. The Korea Herald. Available online: http://www.koreaherald.com/view.php?ud=20200323000744 (accessed on 28 May 2020).

11. Businebusiney-in-Battling-Covid-19s Angeles, Daeg Ohmynews. Available online: http://www.ohmynews. com/NWS_Web/View/at_pg.aspx?CNTN_CD=A0002621873 (accessed on 25 June 2020).

12. Daegu City Deciding to Give 500,000 to 900,000 Won to Recipients, Who Belong to Median-Income Households or Below. Available online: http://www.ohmynews.com/NWS_Web/View/at_pg.aspx?CNTN_ $\mathrm{CD}=\mathrm{A} 0002625088$ (accessed on 25 June 2020).

13. "The Emergency Relief Fund will be Provided in a Pre-Paid Card for Reviving the Local Economy" says the Mayor of Daegu. Available online: https:/www.yna.co.kr/view/AKR20200326101400053 (accessed on 28 May 2020).

14. [Park Myeong Ho's Financial News Column] To Get Over the Corona Pandemic. Available online: https://www.idaegu.co.kr/news/articleView.html?idxno=309440 (accessed on 29 May 2020).

15. To Make a Meaningful Use of Chid Care Points and Disaster Relief Funds. Available online: http: //www.ohmynews.com/NWS_Web/View/at_pg.aspx?CNTN_CD=A0002642483. (accessed on 25 June 2020).

16. Jung, S.J.; Jun, J.Y. Mental Health and Psychological Intervention Amid COVID-19 Outbreak: Perspectives from South Korea. Yonsei Med. J. 2020, 61, 271-272. [CrossRef] [PubMed]

17. Two Months with COVID-19 Shed Your Anxiety as Deep Sleep, Singing, Sun-Bathing are the Health Boosters. Available online: https://www.seoul.co.kr/news/newsView.php?id=20200318018003\&wlog_tag3= naver. (accessed on 27 May 2020).

18. Malta, M.; Rimoin, A.W.; Strathdee, S.A. The coronavirus 2019-nCoV epidemic: Is hindsight 20/20? EClinicalMedicine 2020, 20, 100289. [CrossRef] [PubMed]

19. Cascella, M.; Rajnik, M.; Cuomo, A.; Dulebohn, S.C.; Di Napoli, R. Features, evaluation and treatment coronavirus (COVID-19). In Statpearls; StatPearls Publishing: Treasure Island, Finland, 2020.

20. Garcia, R. Neurobiology of fear and specific phobias. Learn. Mem. 2017, 24, 462-471. [CrossRef]

21. Shin, L.M.; Liberzon, I. The neurocircuitry of fear, stress, and anxiety disorders. Neuropsychopharmacology 2010, 35, 169-191. [CrossRef]

22. Shultz, J.M.; Baingana, F.; Neria, Y. The 2014 Ebola outbreak and mental health: Current status and recommended response. JAMA 2015, 313, 567-568. [CrossRef] 
23. Zhang, Z.; Shi, Z.; Wang, L.; Liu, M. One year later: Mental health problems among survivors in hard-hit areas of the Wenchuan earthquake. Public Health 2011, 125, 293-300. [CrossRef]

24. Mak, I.W.C.; Chu, C.M.; Pan, P.C.; Yiu, M.G.C.; Chan, V.L. Long-term psychiatric morbidities among SARS survivors. Gen. Hosp. Psychiatry 2009, 31, 318-326. [CrossRef] [PubMed]

25. Shigemura, J.; Ursano, R.J.; Morganstein, J.C.; Kurosawa, M.; Benedek, D.M. Public responses to the novel 2019 coronavirus (2019-nCoV) in Japan: Mental health consequences and target populations. Psychiatry Clin. Neurosci. 2020, 74, 281. [CrossRef]

26. Sánchez-Hernández, M.I.; González-López, Ó.R.; Buenadicha-Mateos, M.; Tato-Jiménez, J.L. Work-Life Balance in Great Companies and Pending Issues for Engaging New Generations at Work. Int. J. Environ. Res. Public Health 2019, 16, 5122. [CrossRef]

27. Cook, L.H.; Shinew, K.J. Leisure, work, and disability coping: "I mean, you always need that 'in'group". Leis. Sci. 2014, 36, 420-438. [CrossRef]

28. Choi, E.P.H.; Hui, B.P.H.; Wan, E.Y.F. Depression and Anxiety in Hong Kong during COVID-19. Int. J. Environ. Res. Public Health 2020, 17, 3740. [CrossRef]

29. Panic Disorder, Claustrophobia ... Citizens of Daegu Suffering from Concerns of Anxiety. Available online: https://www.hankookilbo.com/News/Read/202003011523782150 (accessed on 26 May 2020).

30. 2018 Daegu Community Survey Report. Available online: http://stat.daegu.go.kr/statsPublication/ dgSocialSurvey.do (accessed on 10 May 2020).

31. 2008-2018 Regional Health Statistics at a Glance. Available online: https://chs.cdc.go.kr/chs/stats/statsMain.do (accessed on 10 May 2020).

32. Kroenke, K.; Spitzer, R.L.; Williams, J.B. The PHQ-9: Validity of a brief depression severity measure. J. Gen. Intern. Med. 2001, 16, 606-6132. [CrossRef]

33. Kim, S.R.; Shin, H.C.; Lee, D.C.; Kim, C.H.; Seong, E.J.; Lee, G.H.; Kim, J.Y. The Utility of PHQ-2/PHQ-9 Serial Test for the Screening of Major Depressive Disorder in Primary Health Care. Korean Soc. Stress Med. 2011, 19, 405-410.

34. Thibault, J.M.; Steiner, R.W. Psychiatric Briefs. Prim. Care Companion J. Clin. Psychiatry 2004, 6, 270.

35. Beck, A.T.; Ward, C.H.; Mendelson, M.; Mock, J.; Erbaugh, J. An inventory for measuring depression. Arch. Gen. Psychiatry 1961, 4, 561-571. [CrossRef] [PubMed]

36. Kim, J.S. "I am Disgusted at Anyone from Daegu" Hatred for the Region Brings More Horrors than Corona Virus. Available online: https://news.joins.com/article/23767330 (accessed on 28 May 2020).

37. [A Diary of a Corona Warrior] My 60-Year-Old Mum, Right Before retirement, Took Off Her Nurse Uniform to Put on the Armor. Available online: https://news.joins.com/article/23719357 (accessed on 29 May 2020).

38. 7 out of 10 Citizens Said, "Emergency Disaster relief Fund is Helpful.". Available online: http://www. ohmynews.com/NWS_Web/Event/Special/opinion_poll_2019/at_pg.aspx?CNTN_CD=A0002642570\&

CMPT_CD=P0010\&utm_source=naver\&utm_medium=newsearch\&utm_campaign=naver_news (accessed on 26 May 2020).

39. Raschky, P.A.; Schwindt, M. On the Channel and Type of Aid: The Case of International Disaster Assistance. Eur. J. Political Econ. 2012, 28, 119-131. [CrossRef]

40. [LG Hello Vision] The Disaster Relief Fund has Revitalized the Markets. Available online: http://news. lghellovision.net/news/newsView.do?soCode=SC50000000\&idx=276836 (accessed on 27 May 2020).

41. "We can Finally Breathe" A Month after Disaster Relief Fund. Available online: http://www.hani.co.kr/arti/ politics/politics_general/944246.html\#csidx200cbb47c3727c7b89d877092c9beb0 (accessed on 26 May 2020).

42. This South Korean City Once had the Biggest Coronavirus Outbreak Outside of China. Available online: https: //www.weforum.org/agenda/2020/04/south-korean-daegu-china-coronavirus-covid19-cases-virus/ (accessed on 28 May 2020).

43. Yoon, S.G.; Kim, M.H. A Study on the Identity of the Citizens of Daegu Metropolitan and North Gyeongsang Regions. Inst. East-West Thought 2007, 3, 33-64.

44. Regular Briefing on the COVID-19 Response (10 April 2020). Available online: https://www.idaegu.co.kr/ news/articleView.html?idxno=307979 (accessed on 27 May 2020).

45. Jiloha, R.C. COVID-19 and Mental Health. Epidemiol. Int. 2020, 5, 7-9. [CrossRef] 
46. An Analysis on the Panic of Filipinos During COVID-19 Pandemic in the Philippines. Available online: https:// www.researchgate.net/profile/Christian_Jasper_Nicomedes/publication/340081049_An_Analysis_on_the_ Panic_of_Filipinos_During_COVID-19_Pandemic_in_the_Philippines/links/5e7606aa299bf1892cfc4dd3/ An-Analysis-on-the-Panic-of-Filipinos-During-COVID-19-Pandemic-in-the-Philippines.pdf (accessed on 27 May 2020).

47. Li, S.; Wang, Y.; Xue, J.; Zhao, N.; Zhu, T. The Impact of COVID-19 Epidemic Declaration on Psychological Consequences: A Study on Active Weibo Users. Int. J. Environ. Res. Public Health 2020, 17, 2032. [CrossRef] [PubMed]

(C) 2020 by the authors. Licensee MDPI, Basel, Switzerland. This article is an open access article distributed under the terms and conditions of the Creative Commons Attribution (CC BY) license (http://creativecommons.org/licenses/by/4.0/). 